\title{
PENGARUH LIKUIDITAS DAN STRUKTUR MODAL TERHADAP NILAI PERUSAHAAN DENGAN PROFITABILITAS SEBAGAI VARIABEL INTERVENING PADA PERUSAHAAN YANG TERDAFTAR DI BURSA EFEK INDONESIA
}

\author{
Maria Dominika Edo Hera \\ Fakultas Ekonomi dan Bisnis UPN "Veteran" Jakarta \\ marnidominika@gmail.com \\ Dahlia Pinem \\ Fakultas Ekonomi dan Bisnis UPN "Veteran” Jakarta \\ pinem_dahlia@yahoo.com
}

\begin{abstract}
The purpose of this study was to examine the effect of liquidity and capital structure on firm value with profitability as intervening variable. The population in this study is the consumer goods sector companies listed in the Indonesia Stock Exchange from 20132016. Sampling technique using purposive sampling method, with samples produced as many as 20 companies from 37 companies of consumer goods sector. This hypothesis testing uses Path Analysis with E-Views 9.0 and a significance level of 5\%. Test results of the testing showed that (1) liquidity has a significant effect on profitability with significance level 0,0192 <0,05. (2) capital structure has a significant effect on profitability with a significance level of $0.0003<0,05$. (3) liquidity has no effect on firm value because of the significance level of 0.09982>0.05. (4) capital structure has a significant effect on firm value with significance level $0,0000<0,05$. (5) profitability has a significant effect on firm value with significance level of $0.0001<0,05$. (6) liquidity and capital structure has no effect on firm value through profitability because the indirect influence of both variables is smaller than direct influence.
\end{abstract}

Keywords: Liquidity, Capital Structure, Profitability and Firm Value.

\section{PENDAHULUAN}

1.1 Latar Belakang Penelitian

Pada dasarnya, setiap perusahaan baik yang bergerak dalam bidang perdagangan, pelayanan jasa maupun manufaktur mempunyai tujuan yang sama, yaitu untuk mendapatkan keuntungan atau laba serta menjaga kelangsungan hidup perusahaan. Seiring dengan pertumbuhan ekonomi dan pembangunan yang menandai lajunya globalisasi, perusahaan semakin terdorong untuk meningkatkan daya saing. Banyak perusahaan didirikan dengan tujuan untuk meningkatkan nilai perusahaan agar dapat memberikan kemakmuran bagi pemegang saham dan juga perusahaan itu sendiri. Masalah yang sering timbul dalam perusahaan adalah bagaimana perusahaan memperoleh dana dan mengalokasikan dana tersebut seefektif mungkin. Maka dari itu perusahaan selalu dituntut untuk mempunyai strategi yang baik agar dapat memenangi persaingan demi kelangsungan hidup perusahaan.

Cara memenangi persaiangan adalah cara mengelola perusahaan dengan sebaik mungkin. Suatu perusahaan dapat dikatakan berhasil dan mencapai kesuksesan adalah jika perusahaan tersebut mampu bersaing dan memenangi persaingan, sehingga menghasilkan laba bagi perusahaan. Oleh karena itu, pihak manajemen perusahaan harus mengambil keputusan yang tepat dan dapat dipertanggungjawabkan. Apabila perusahaan meningkatkan jumlah utang sebagai sumbar dananya, maka perusahaan harus mampu mengelola dana dari utang tersebut secara produktif agar tidak memberikan pengaruh negatif dan berdampak pada penurunan profitabilitas perusahaan. Sebaliknya apabila 
dana dari utang tersebut dikelola dan digunakan dengan baik profitabilitas perusahaan akan meningkat.

Nilai perusahaan merupakan gambaran dari kesejahteraan pemilik dan pemegang sahamnya. Semakin tinggi nilai perusahaan, semakin sejahtera pula pemiliknya. Untuk itu, nilai perusahaaan di mata investor dan kreditur sangat penting untuk diketahui. Nilai perusahaan akan memberikan sinyal positif di mata investor untuk menanamkan modal pada sebuah perusahaan, sedangkan bagi pihak kreditur nilai perusahaan mencerminkan kemampuan perusahaan untuk membayar utangnya sehingga pihak kreditur tidak merasa khawatir dalam memberikan pinjaman kepada perusahaan tersebut. Struktur modal merupakan masalah yang penting bagi perusahaan karena baik buruknya struktur modal akan mempunyai efek-efek langsung terhadap posisi financial perusahaan yang pada akhirnya akan mempengaruhi nilai perusahaan. Kesalahan dalam menentukan struktur modal akan mempunyai dampak yang luas terutama apabila perusahaan terlalu besar dalam menggunakan hutang, maka beban tetap yang harus ditanggung perusahaan semakin besar pula. Profitabilitas merupakan daya tarik utama bagi pemilik perusahaan (pemegang saham) karena profitabilitas adalah hasil yang diperoleh melalui usaha manajemen atas dana yang di investasikan para pemegang saham dan juga mencerminkan pembagian laba yang menjadi haknya yaitu seberapa banyak yang di investasikan kembali dan seberapa banyak yang dibayarkan sebagai dividen tunai ataupun dividen saham kepada mereka. Rasio ini juga memberikan ukuran tingkat efektivitas manajemen suatu perusahaan. Hal ini ditunjukkan oleh laba yang dihasilkan dari penjualan dan pendapatan investasi. Tujuannya adalah agar terlihat perkembangan perusahaan dalam rentang waktu tertentu, baik penurunan atau kenaikan sekaligus mencari penyebab perubahan tersebut (Hamidy Rusdi, dkk, 2015).

Nilai likuiditas yang tinggi mencerminkan kemampuan perusahaan yang tinggi untuk memenuhi kewajiban jangka pendeknya. Perusahaan yang memiliki nilai likuiditas yang baik akan dianggap memiliki kinerja yang baik oleh investor. Likuiditas merupakan kemampuan perusahaan untuk memenuhi kewajiban finansial yang berjangka pendek tepat pada waktunya. Likuiditas yang tinggi menunjukkan kekuatan perusahaan dari segi kemampuan untuk memenuhi hutang lancar dari harta lancar yang dimiliki sehingga hal ini meningkatkan kepercayaan pihak luar terhadap perusahaan tersebut (Mirza dan Khuzaini, 2016).

\subsection{Perumusan Masalah}

Berdasarkan uraian latar belakang masalah di atas, rumusan masalah dalam penelitian ini adalah sebagai berikut:

a. Apakah Likuiditas berpengaruh terhadap Profitabilitas

b. Apakah Struktur Modal berpengaruh terhadap Profitabilitas

c. Apakah Profitabilitas berpengaruh terhadap Nilai Perusahaan

d. Apakah Likuiditas berpengaruh terhadap Nilai Perusahaan

e. Apakah Struktur Modal berpengaruh terhadap Nilai Perusahaan

f. Apakah Likuiditas berpengaruh terhadap Nilai Perusahaan dengan Profitabilitas sebagai variabel intervening

g. Apakah Struktur Modal berpengaruh terhadap Nilai Perusahaan dengan Profitabilitas sebagai variabel intervening

\section{Tinjauan Pustaka dan Pengembangan Hipotesis}

\subsection{Nilai Perusahaan}

Nilai perusahaan menggambarkan kesejahteraan dari pemilik perusahaan dan pemegang saham. Semakin tinggi nilai perusahaan, maka semakin baik kinerja perusahaan di mata investor. Menurut Harmono (2016, hlm 50), "Nilai perusahaan dapat diukur melalui nilai harga saham di pasar, berdasarkan terbentuknya harga saham perusahaan di pasar yang merupakan refleksi penilaian oleh public terhadap kinerja perusahaan secara riil".

Menurut Sudana (2015, hlm 9) "Nilai perusahaan merupakan nilai sekarang dari arus pendapatan atau kas yang diharapkan diterima pada masa yang akan datang". Nilai 
perusahaan akan memberikan sinyal positif kepada investor untuk berinvestasi di perusahaan tersebut.

Pengukuran yang digunakan untuk nilai perusahaan sebagai variabel dependen (Y) adalah Price Book Value (PBV)

Rumus: Price Book Value

\subsection{Likuiditas}

$$
\mathrm{PBV}=
$$

Harga pasar saham

Nilai buku per saham

Likuiditas merupakan ukuran kinerja perusahaan dalam kemampuan untuk memenuhi kewajiban keuangan yang segera harus dilunasi yaitu kewajiban keuangan yang jatuh temponya sampai dengan 1 tahun. (Sitanggang, 2012, hlm 22). Menurut Sudana (2015, hlm 24), mengatakan bahwa 'likuiditas adalah kemampuan perusahaan untuk memenuhi kewajiban keuangan jangka pendek'.

Ada kalanya perusahaan tidak mampu untuk membayar seluruh atau sebagian utang (kewajibannya) yang telah jatuh tempo pada saat ditagih. Atau terkadang perusahaan juga tidak memiliki dana untuk membayar utangnya tepat waktu. Hal ini akan mengganggu hubungan baik antara perusahaan dengan para kreditor atau dengan para distributor.

Pengukuran yang digunakan untuk likuiditas sebagai variabel independen $\left(\mathrm{X}_{1}\right)$ adalah Current Ratio (CR) atau rasio lancar.

Rumus:

\begin{tabular}{lll} 
Rasio & Lancar & Harta lancer \\
\cline { 3 - 3 } & & \\
\cline { 3 - 3 }
\end{tabular}

\subsection{Struktur modal}

Struktur modal (capital structure), adalah pembelanjaan jangka panjang suatu perusahaan yang diukur dengan perbandingan utang jangka panjang dengan modal sendiri (Sudana, 2015, hlm 164). Dalam menentukan srtuktur modal optimal, sumber pembiayaan yang dihitung adalah pembiayaan utang jangka pendek permanen, utang jangka panjang dan modal sendiri. Utang jangka pendek yang bersifat musiman tidak diperhitungkan karena sumber pembiayaan pada umumnya hanya bersifat sementara. Pengukuran yang digunakan untuk struktur modal sebagai variabel independen $\left(\mathrm{X}_{2}\right)$ adalah Debt to Equity Ratio (DER).

Rumus:

$$
\text { DER }=\frac{\text { Total utang }}{\text { Modal sendiri }}
$$

\subsection{Profitabilitas}

Menurut Kasmir (2014, hlm 196) menyatakan bahwa 'rasio profitabilitas merupakan rasio untuk menilai kemampuan perusahaan dalam mencari keuntungan. Rasio ini juga memberikan ukuran tingkat efektivitas manajemen suatu perusahaan. Hal ini ditunjukkan oleh laba yang dihasilkan dari penjualan dan pendapatan investasi. Pengukuran yang digunakan untuk profitabilitas sebagai variabel intervening $\left(\mathrm{X}_{3}\right)$ adalah Return On Assets (ROA).

Rumus:

$$
\mathrm{ROA}=\frac{\text { EAT }}{\text { Total Aset }}
$$

\subsection{Kerangka Pemikiran dan Pengembangan Hipotesis}

Pengaruh Likuiditas Terhadap Profitabilitas

Sitanggang (2012, hlm: 35) menyatakan bahwa "Likuiditas tinggi atau risiko rendah akan mengakibatkan tingkat profitabilitas yang rendah, atau sebaliknya likuiditas rendah atau risiko tinggi akan mengakibatkan tingkat profitabilitas yang tinggi." Sebuah perusahaan dalam menjalankan operasinya membutuhkan dana yang sangat besar, baik untuk produksi, maupun untuk investasi. Kebutuhan dana ini tidak dapat sepenuhnya dipenuhi 
dengan modal sendiri. Oleh karena itu, perusahaan harus melakukan penundaan pembayaran beberapa kewajiban. Utang yang dimiliki oleh perusahaan harus dikelola sedemikian rupa sehingga tidak menambah beban bagi perusahaan yang pada akhirnya dapat menyebabkan kerugian.

Sudana (2015, hlm 24), mengatakan bahwa likuiditas adalah kemampuan perusahaan untuk memenuhi kewajiban keuangan jangka pendek. Likuiditas dalam penelitian ini berfokus pada rasio lancar atau current ratio. Rasio lancar merupakan perbandingan antara aktiva lancar dan hutang lancar. Likuiditas perusahaan berbanding terbalik dengan profitabilitas. Semakin tinggi likuiditas perusahaan maka kemampuan perusahaa untuk menghasilkan laba semakin rendah. Penelitian Sariyana, B, dkk (2016), Tania Iskandar,dkk (2014), Velnampy.T \& Vickneswaran Anojan (2014) menyatakan bahwa variabel Likuiditas tidak berpengaruh signifikan terhadap Profitabilitas, sedangkan penelitian dari Bunga Asri Novita dan Sofie (2015), Sylvia Chen dan Hening Widi Oetomo (2015) menyatakan bahwa Likuiditas berpengaruh signifikan terhadap Profitabilitas. Berdasarkan teori dan penelitian terdahulu mengenai likuiditas dan profitabilitas maka penulis ingin menguji apakah likuiditas yang diukur dengan current ratio berpengaruh terhadap profitabilitas. Maka hipotesis pertama (H1) yang diajukan dalam penelitian imi adalah:

H1: Likuiditas berpengaruh signifikan terhadap Profitabilitas

\section{Pengaruh Struktur Modal Terhadap Profitabilitas}

Struktur modal akan berpengaruh positif terhadap profitabilitas apabila berada pada struktur modal yang optimum. Jika penggunaan hutang yang lebih banyak daripada modal sendiri akan mengakibatkan menurunnya profitabilitas perusahaan. Sitanggang (2012, hlm 26) mengatakan bahwa 'Semakin besar DER berarti semakin besar peranan utang dalam membiayai aset perusahaan dan sebaliknya. Struktur modal (capital structure), adalah pembelanjaan jangka panjang suatu perusahaan yang diukur dengan perbandingan utang jangka panjang dengan modal sendiri. (Sudana 2015, hlm 164)

Dalam menentukan srtuktur modal optimal, sumber pembiayaan yang dihitung adalah pembiayaan utang jangka pendek permanen, utang jangka panjang dan modal sendiri. Utang jangka pendek yang bersifat musiman tidak diperhitungkan karena sumber pembiayaan pada umumnya hanya bersifat sementara. Apabila suatu perusahaan dalam memenuhi dananya mengutamakan pemenuhan dengan sumber dana dari dalam perusahaan. Jika kebutuhan dana semakin meningkat karena pertumbuhan perusahaan sedangkan dana dari dalam perusahaan sudah digunakan semua maka perusahaan menggunakan dana dari luar perusahaan baik hutang maupun mengeluarkan saham baru. Berdasarkan teori mengenai struktur modal dan profitabilitas maka penulis ingin menguji apakah struktur modal berpengaruh terhadap profitabilitas.

H2: Struktur Modal berpengaruh signifikan terhadap Profitabilitas

\section{Pengaruh Profitabilitas Terhadap Nilai Perusahaan}

Profitabilitas adalah kemampuan perusahaan untuk memperoleh laba atau keuntungan (Kasmir, $2014 \mathrm{hlm}$ 196). Dengan meningkatnya profitabilitas maka laba per lembar saham pada perusahaan juga akan meningkat. Hal ini akan meningkatkan nilai perusahaan. (Mirza Chayatun, 2016). Signalling theory menjelaskan dimana investor akan meningkatkan permintaan saham apabila profitabilitas perusahaan meningkat, dan di sisi lain juga meningkatkan nilai perusahaan. Didukung oleh penelitian dari Hamidy, R, dkk 2015, Mirza Chayani dan Khuzaini (2016), I Gede Gora Pratama dan Ni Gusti Putu (2016) yang menyatakan bahwa Profitabilitas berpengaruh terhadap Nilai Perusahaan.

Berdasarkan teori dan penelitian terdahulu mengenai profitabilitas dan nilai perusahaan maka penulis ingin menguji apakah profitabilitas berpengaruh terhadap nilai perusahaan.

H3: Profitabilitas berpengaruh signifikan terhadap Nilai Perusahaan 


\section{Pengaruh Likuiditas Terhadap Nilai Perusahaan}

Sudana (2015, hlm 24), mengatakan bahwa 'likuiditas adalah kemampuan perusahaan untuk memenuhi kewajiban keuangan jangka pendek'. Perusahaan yang memiliki tingkat likuiditas yang tinggi berarti perusahaan memiliki dana internal yang cukup untuk membiayai kewajiban jangka pendeknya. Sehingga penggunaan mengurangi penggunaan utang. Maka semakin baik kinerja perusahaan di mata investor. Apabila nilai likuiditas tinggi maka akan meningkatkan nilai perusahaan. Didukung oleh penelitian dari Corry dan Rustam yang menyatakan bahwa Likuiditas berpengaruh terhadap Nilai Perusahaan. Berdasarkan teori dan penelitian terdahulu mengenai likuiditas dan nilai perusahaan maka penulis ingin menguji apakah likuiditas berpengaruh terhadap nilai perusahaan.

H4: Likuiditas berpengaruh signifikan terhadap Nilai Perusahaan

\section{Pengaruh Struktur Modal Terhadap Nilai Perusahaan}

Struktur modal (capital structure), adalah pembelanjaan jangka panjang suatu perusahaan yang diukur dengan perbandingan utang jangka panjang dengan modal sendiri (Sudana 2015, hlm 164).

Trade-off theory menjelaskan bahwa peningkatan nilai perusahaan diakibatkan karena posisi struktur modal berada di bawah titik optimal dan penambahan hutang. Sebaliknya, penurunan nilai perusahaan diakibatkan oleh posisi struktur modal berada di atas titik optimal. Oleh karena itu, jika titik target struktur modal optimal belum terpenuhi, maka berdasarkan trade-off theory memprediksi adanya hubungan yang positif terhadap nilai perusahaan. (Hamidy, 2014). Didukung oleh penelitian dari Hamidy, R, dkk 2015, Mirza Chayani dan Khuzaini (2016), I Gede Gora Pratama dan Ni Gusti Putu (2016) yang menyatakan bahwa Struktur Modal berpengaruh terhadap Nilai Perusahaan.

Berdasarkan teori dan penelitian terdahulu mengenai struktur modal dan nilai perusahaan maka penulis ingin menguji apakah struktur modal berpengaruh terhadap nilai perusahaan.

H5: Struktur Modal berpengaruh signifikan terhadap Nilai Perusahaan

\section{Pengaruh Likuiditas Terhadap Nilai Perusahaan dengan Profitabilitas sebagai variabel intervening}

Likuiditas adalah kemampuan perusahaan untuk memenuhi kewajiban keuangan jangka pendek (Sudana (2015, hlm 24). Perusahaan yang memiliki tingkat likuiditas yang tinggi berarti perusahaan memiliki dana internal yang cukup untuk membiayai kewajiban jangka pendeknya. Sehingga mengurangi penggunaan utang. Maka semakin baik kinerja perusahaan di mata investor. Apabila nilai likuiditas tinggi maka akan meningkatkan maka akan berpotensi untuk meningkatkan keuntungan atau laba bagi perusahaan sehingga nilai perusahaan juga akan meningkat. Didukung oleh penelitian dari Yudha Dharma dan Ni Luh (2013) yang menyatakan bahwa Likuiditas berpengaruh terhadap Nilai Perusahaan melalui Profitabilitas.

Berdasarkan teori dan penelitian terdahulu mengenai Likuiditas dan Nilai Perusahaan dengan Profitabilitas sebagai variabel intervening, maka penulis ingin menguji apakah profitabiliats mampu memediasi likuiditas terhadap nilai perusahaan.

H6: Likuiditas berpengaruh signifikan terhadap Nilai Perusahaan dengan Profitabilitas sebagai variabel intervening.

\section{Pengaruh Struktur Modal Terhadap Nilai Perusahaan dengan Profitabilitas sebagai variabel intervening}

Struktur modal (capital structure), adalah pembelanjaan jangka panjang suatu perusahaan yang diukur dengan perbandingan utang jangka panjang dengan modal sendiri (Sudana 2015, hlm 164). Peningkatan nilai perusahaan diakibatkan karena posisi struktur modal berada di bawah titik optimal dan penambahan hutang. Sebaliknya, penurunan nilai perusahaan diakibatkan oleh posisi struktur modal berada di atas titik optimal (Hamidy, 2014). 
Perusahaan yang meningkatkan penggunaan utangnya maka profitabilitasnya akan mengalami peningkatan. Peningkatan profitabilitas akan menjadi ketertarikan tersendiri bagi para investor sehingga permintaan terhadap saham akan meningkat yang kemudian secara langsung akan meningkatkan nilai perusahaan. Hal ini didukung oleh penelitian dari Hamidy rusdi, dkk (2014) dan Mirza Chayatun dan Khuzaini (2015) yang menyatakan bahwa Profitabilitas mampu memediasi struktur modal terhadap Nilai Perusahaan.

Berdasarkan teori dan penelitian terdahulu mengenai struktur modal dan nilai perusahaan dengan profitabilitas sebagai variabel intervening, maka penulis ingin menguji apakah profitabilitas mampu memediasi struktur modal terhadap nilai perusahaan.

H7: Struktur Modal berpengaruh signifikan terhadap Nilai Perusahaan dengan Profitabilitas sebagai variabel intervening.

3. METODE PENELITIAN

\subsection{Populasi dan Sampel}

Populasi yang digunakan dalam penelitian ini adalah perusahaan sektor barang konsumsi yang terdaftar di Bursa Efek Indonesia (BEI) selama 4 periode, dari tahun 2013 sampai dengan tahun 2016. Metode pengambilan sampel menggunakan purposive sampling method yaitu berdasarkan kriteria tertentu yang diinginkan.

\subsection{Jenis dan Sumber data}

Jenis data yang digunakan dalam penelitian ini merupakan data kuantitatif. Sedangkan sumber data yang digunakan merupakan jenis data sekunder. Data tersebut berupa laporan keuangan tahunan perusahaan manufaktur yang terdaftar di Bursa Efek Indonesia (BEI) selama 4 periode, dari tahun 2013 sampai dengan tahun 2016, yang didokumentasikan dalam www.idx.co.id dan www.icamel.id.

\subsection{Pengujian Hipotesis}

Penelitian ini menggunakan regresi data panel dan analisis jalur, untuk menguji hipotesis atau adanya pengaruh dalam variabel dependen (bebas) dengan variabel independen (terikat).

Menurut Ajija dkk (2011, hlm 52) bentuk umum persamaan regresi data panel yaitu:

Yit $\quad=\beta 0+\beta 1 X 1 t+\beta 2 X 2 t+\beta 3 X 3 t+\varepsilon t$

Keterangan:

Yit = Nilai Perusahaan diukur dengan PBV

$\mathrm{X} 1=$ Likuiditas diukur dengan Current Ratio (CR)

X2 = Struktur Modal diukur dengan Debt to Equity Ratio (DER)

$\mathrm{X} 3=$ Profitabilitas diukur dengan Return On Assets (ROA)

$\beta \quad=$ Konstanta

I $\quad=$ Nama perusahaan sektor barang konsumsi

$\mathrm{t} \quad=$ Periode waktu

et $\quad=$ Error Term

\section{HASIL DAN PEMBAHASAN}

\subsection{Analisis Data}

\subsubsection{Statistik Deskriptif}

Berdasarkan hasil pengolahan statistik deskriptif data dengan menggunakan E-views versi 9.0 diperoleh nilai hasil perhitungan sebagai berikut:

Tabel 1. Statistik Deskriptif

\begin{tabular}{lcccc}
\hline & PBV & CR & DER & ROA \\
\hline Mean & 5.331875 & 260.9103 & 0.769125 & 13.27963 \\
\hline Maximum & 45.46000 & 760.3800 & 3.030000 & 65.72000 \\
\hline Minimum & 0.230000 & 51.39000 & 0.180000 & 1.540000 \\
\hline Std. Dev. & 7.233617 & 145.9471 & 0.504865 & 10.93339 \\
\hline Observations & 80 & 80 & 80 & 80 \\
\hline
\end{tabular}

Sumber: Output E-Views 9.0, data diolah 
Dari hasil tabel 1 di atas diketahui bahwa sampel yang digunakan dalam penelitian ini adalah sebanyak 20 sampel perusahaan dengan periode penelitian selama 4 tahun, maka jumlah sampel data $\mathrm{N}$ adalah 80 dapat dijelaskan sebagai berikut: Variabel Nilai Perusahaan yang diproksikan dengan Price Book Value (PBV), yaitu perbandingan antara harga saham di pasar dengan nilai buku suatu saham. Semakin tinggi rasio PBV maka semakin berhasil perusahaan dalam menciptakan nilai bagi pemegang saham. Dari tabel 6 diatas rata-rata Price Book Value (PBV) dari 20 perusahaan selama 4 tahun adalah sebesar 5,331875, di mana nilai minimum dari PBV adalah sebesar 0,230000 yang dimiliki oleh perusahaan Handaya Mandala Sampoerna Tbk (HMSP) yaitu sebesar 0,23 pada tahun 2016. Nilai maksimum dari PBV sebesar 45,46000 yang dimiliki oleh perusahaan Multi Bintang Indonesia Tbk (MLBI) sebesar 45,46 pada tahun 2014. Sedangkan standar deviasi PBV sebesar 7,233617.

Variabel likuiditas diukur dengan Current Ratio (CR). Pada tabel 6 diatas nilai rata-rata dari CR dari 20 perusahaan selama 4 tahun sebesar 260,9103. Dengan nilai minimum dari CR adalah sebesar 51,39000 yang dimiliki oleh perusahaan Multi Bintang Indonesia Tbk (MLBI) sebesar 51,39 pada tahun 2014, dan nilai maksimum dari CR adalah sebesar 760,3800 yang dimiliki oleh perusahaan Delta Djakarta Tbk (DLTA) sebesar 760,38 pada tahun 2016. Sedangkan standar deviasi CR sebesar 145,9471.

Variabel struktur modal yang diukur dengan Debt to Equity Ratio (DER). Dari hasil pada tabel 6 diatas rata-rata penggunaan DER pada 20 perusahaan selama 4 tahun adalah sebesar 0,769125. Dengan nilai minimum dari DER sebesar 0,180000 yang dimiliki oleh perusahaan Delta Djakarta Tbk (DLTA) sebesar 0,18 pada tahun 2016, dan nilai maksimum dari DER sebesar 3,030000 yang dimiliki oleh perusahaan Multi Bintang Indonesia Tbk (DLTA) sebesar 3,03 pada tahun 2014. Sedangkan standar deviasi dari DER sebesar 0,504865.

Variabel profitabilitas diukur dengan Return On Assets (ROA). Dari hasil pada tabel 6 diatas rata-rata dari ROA pada 20 perusahaan selama 4 tahun adalah sebesar 13,27963. Dengan nilai minimum dari ROA sebesar 1,540000 yang dimiliki oleh perusahaan Pyridam Farma Tbk (PYFA) yaitu sebesar 1,54 pada tahun 2014, dan nilai maksimum dari ROA sebesar 65,72000 yang dimiliki oleh perusahaan Multi Bintang Indonesia Tbk (MLBI) sebesar 65,72 pada tahun 2013. Sedangkan standar deviasi dari ROA sebesar 10,93339 .

Tabel 2. Fixed Effect Model Sub struktur I

\begin{tabular}{|c|c|c|c|c|}
\hline \multicolumn{5}{|c|}{$\begin{array}{l}\text { Dependent Variable: ROA } \\
\text { Method: Panel Least Squares } \\
\text { Date: } 04 / 06 / 17 \text { Time: } 22: 47 \\
\text { Sample: } 20132016 \\
\text { Periods included: } 4 \\
\text { Cross-sections included: } 20 \\
\text { Total panel (balanced) observations: } 80\end{array}$} \\
\hline Variable & Coefficient & Std. Error & t-Statistic & Prob. \\
\hline $\mathrm{C}$ & 25.74162 & 3.426199 & 7.513170 & 0.0000 \\
\hline $\mathrm{CR}$ & -0.018860 & 0.007826 & -2.409863 & 0.0192 \\
\hline DER & -9.805094 & 2.528741 & -3.877461 & 0.0003 \\
\hline
\end{tabular}

Sumber : Output E-Views 9.0, data diolah

Berdasarkan hasil pengujian regresi data panel di atas maka dapat ditulis persamaan model regresi sebagai berikut:

ROA $=25,74162-0,018860$ (CR)-9,805094 (DER)

Nilai koefisien regresi Profitabilitas yang diukur dengan Retuen On Assets dapat dilihat dari nilai konstanta (C) sebesar 25,74162. Menunjukkan bahwa jika nilai variabel 
independen yaitu Likuiditas dan Struktur Modal dianggap konstanta atau 0 (nol), maka Profitabilitas akan mengalami peningkatan sebesar 25,74162.

Nilai koefisien regresi Likuidtas yang diukur dengan Current Ratio (CR) menunjukkan arah yang negatif yaitu sebesar $-0,018860$. Artinya bahwa tiap terjadi kenaikan CR sebesar satu persen (dengan asumsi bahwa nilai koefisien variabel bebas lain adalah tetap atau tidak berubah), maka akan terjadi peningkatan Profitabilitas sebesar 0,018860. Dan sebaliknya apabila terjadi penurunan CR sebesar satu persen maka Profitabilitas akan mengalami penurunan sebesar 0,018860 .

Nilai koefisien regresi Struktur Modal yang diukur dengan Debt to Equity Ratio (DER) menunjukkan arah yang negatif yaitu sebesar $-9,805094$. Artinya jika terjadi kenaikan DER sebesar satu persen persen (dengan asumsi bahwa nilai koefisien variabel bebas lain adalah tetap atau tidak berubah), maka akan terjadi penurunan profitbilitas sebesar 9,805094. Dan sebaliknya apabila DER mengalami penurunan sebesar satu persen maka Profitabilitas akan mengalami peningkatan sebesar 9,805094.

Tabel 3. Fixed Effect Model Sub struktur II

\begin{tabular}{|c|c|c|c|c|}
\hline \multicolumn{5}{|c|}{$\begin{array}{l}\text { Dependent Variable: PBV } \\
\text { Method: Panel Least Squares } \\
\text { Date: } 04 / 06 / 17 \text { Time: } 16: 34 \\
\text { Sample: } 20132016 \\
\text { Periods included: } 4 \\
\text { Cross-sections included: } 20 \\
\text { Total panel (balanced) observations: } 80\end{array}$} \\
\hline Variable & Coefficient & Std. Error & t-Statistic & Prob. \\
\hline $\mathrm{CR}$ & -9.252982 & 0.004030 & -0.002296 & 0.9982 \\
\hline DER & 10.33274 & 1.393291 & 7.416073 & 0.0000 \\
\hline ROA & 0.270759 & 0.064472 & 4.199627 & 0.0001 \\
\hline $\mathrm{C}$ & -6.208465 & 2.363137 & -2.627213 & 0.0110 \\
\hline
\end{tabular}

Sumber: Output E-Views 9.0, data diolah

Berdasarkan hasil pengujian dari model regresi data panel di atas, maka dapat ditulis persamaan model regresi sebagai berikut:

PBV $=-6,208465-9,252982(\mathrm{CR})+10,33274(\mathrm{DER})+0,270759(\mathrm{ROA})$

Nilai koefisien regresi nilai perusahaan yang diukur dengan Price Book Value (PBV), dapat dilihat dari nilai konstanta (C) sebesar -6,208465. Jika nilai variabel bebas yaitu Likuiditas, Struktur Modal dan Profitabilitas dianggap konstanta atau 0 (nol), maka Nilai Perusahaan yang didapatkan sebesar 6,208465.

Nilai koefisien regresi Current Ratio (CR) menunjukkan arah yang negatif yaitu sebesar 9,252982. Hal ini menunjukkan bahwa apabila terjadi kenaikan CR sebesar satu persen (dengan asumsi bahwa nilai koefisien variabel bebas lain adalah tetap atau tidak berubah), maka Nilai Perusahaan akan mengalami peningkatan sebesar 9,252982. Dan sebaliknya apabila terjadi penurunan CR sebesar satu persen maka akan menurunkan nilai perusahaan sebesar 9,252982 .

Nilai koefisien regresi Debt to Equity Ratio (DER) menunjukkan arah positif yaitu sebesar 10,33274. Artinya bahwa setiap terjadi kenaikan DER sebesar satu persen (dengan asumsi bahwa nilai koefisien variabel beas lain tetap atau tidak berubah), maka Nilai perusahaan akan mengalami peningkatan sebesar 10,33274. Dan sebaliknya apabila terjadi penurunan DER sebesar satu persen maka akan menurunkan Nilai Perusahaan sebesar 10,3274.

Nilai koefisien regresi Return On Assets (ROA) menunjukkan arah positif yaitu sebesar 0,270759. Artinya setiap terjadi kenaikan ROA sebesar satu persen (dengan asumsi bahwa nilai koefisien variabel beas lain tetap atau tidak berubah), maka Nilai Perusahaan 
akan mengalami peningkatan sebesar 0,270759. Dan sebaliknya apabila terjadi penurunan ROA sebesar satu persen maka akan menurunkan Nilai Perusahaan sebesar 0,270759.

\subsection{Uji Hipotesis}

\subsubsection{Uji t}

Tabel 4. Hasil Uji t Sub Struktur I Variabel dependen ROA

\begin{tabular}{crrrr}
\hline Variable & Coefficient & Std. Error & t-Statistic & Prob. \\
\hline C & 25.74162 & 3.426199 & 7.513170 & 0.0000 \\
CR & -0.018860 & 0.007826 & -2.409863 & 0.0192 \\
DER & -9.805094 & 2.528741 & -3.877461 & 0.0003
\end{tabular}

Sumber: Output E-Views 9.0, data diolah

\section{Pengaruh Likuiditas Terhadap Profitabilitas}

Variabel Likuiditas yang diukur dengan Current Ratio (CR) memiliki $t_{\text {hitung }}$ sebesar 2,409863 dengan nilai $t_{\text {tabel }}$ sebesar $-1,99125$ maka $t_{\text {hitung }}>t_{\text {tabel. }}$ Nilai signifikansi variabel Likuiditas adalah 0,0192 nilai tersebut lebih dari 0,05 $(0,0192<0,05)$. Artinya Likuiditas berpengaruh signifikan terhadap Profitabilitas.

\section{Pengaruh Struktur Modal Terhadap Profitabilitas}

Variabel Struktur Modal yang diukur dengan Debt to Equity Ratio (DER) memiliki thitung sebesar -3,877461 dengan nilai $t_{\text {tabel }}$ sebesar 1,99125 maka $t_{\text {hitung }}>t_{\text {tabel. }}$. Nilai signifikansi variabel struktur modal adalah $0,0003<0,05$. Maka $\mathrm{H}_{0}$ ditolak dan $\mathrm{H}_{\mathrm{a}}$ diterima. Dengan kata lain Struktur Modal berpengaruh signifikan terhadap Profitabilitas.

Tabel 5. Hasil Uji t Sub Struktur II Variabel dependen PBV

\begin{tabular}{crrrr}
\hline Variable & Coefficient & Std. Error & t-Statistic & Prob. \\
\hline CR & -9.252982 & 0.004030 & -0.002296 & 0.9982 \\
DER & 10.33274 & 1.393291 & 7.416073 & 0.0000 \\
ROA & 0.270759 & 0.064472 & 4.199627 & 0.0001 \\
C & -6.208465 & 2.363137 & -2.627213 & 0.0110 \\
\hline
\end{tabular}

Sumber: E-Views 9.0, data diolah

Berdasarkan hasil data olah statistik pada tabel 18 di atas dengan program E-Views 9.0, maka dapat disimpulkan sebagai berikut:

\section{Pengaruh Likuiditas terhadap Nilai Perusahaan}

Variabel Likuiditas yang diproksikan dengan Current Ratio (CR) memiliki nilai signifikansi sebesar $0.9982>0,05$. Dan Nilai $t_{\text {hitung }}$ sebesar $-0,002296$ sedangkan nilai $t_{\text {tabel }}$ sebesar 1,99167 maka $t_{\text {hitung }}<t_{\text {tabel. }}$. Sehingga dapat disimpulkan bahwa $\mathrm{H}_{0}$ diterima dan $\mathrm{H}_{\mathrm{a}}$ ditolak. Artinya Likuiditas tidak berpengaruh signifikan terhadap Nilai Perusahaan.

\section{Pengaruh Struktur Modal terhadap Nilai Perusahaan}

Variabel Struktur Modal yang diproksikan dengan Debt to Equity Ratio (DER), memiliki nilai signifikansi sebesar $0,0000<0,05$. Dan nilai $t_{\text {hitung }}$ sebesar 7,416073 sedangkan nilai $\mathrm{t}_{\text {tabel }}$ sebesar 1,99167 maka $\mathrm{t}_{\text {hitung }}>\mathrm{t}_{\text {tabel }}$. Sehingga dapat disimpulkan bahwa $\mathrm{H}_{0}$ ditolak dan $\mathrm{H}_{\mathrm{a}}$ diterima. Artinya Struktur Modal berpengaruh signifikan terhadap Nilai Perusahaan.

\section{Pengaruh Profitabilitas terhadap Nilai Perusahaan}

Variabel Profitabiliats yang diproksikan dengan Return On Assets (ROA), memiliki nilai signifikansi sebesar $0,0001<0,05$. Dan nilai $t_{\text {hitung }}$ sebesar 4,199627 sedangkan nilai $t_{\text {tabel }}$ sebesar 1,99167 maka $t_{\text {hitung }}>t_{\text {tabel }}$ sehingga dapat disimpulkan bahwa $\mathrm{H}_{0}$ ditolak dan $\mathrm{H}_{\mathrm{a}}$ diterima. Artinya Profitabilitas berpengaruh signifikan terhadap Nilai Perusahaan. 


\subsubsection{Uji Koefisien Determinasi (Adjusted $R^{2}$ )}

Tabel 6. Uji Koefisien Determinasi (Adjusted $R^{2}$ ) Sub struktur I Variabel dependen ROA

\begin{tabular}{lrll}
\hline R-squared & 0.864924 & Mean dependent var & 13.27963 \\
Adjusted R-squared & 0.816017 & S.D. dependent var & 10.93339 \\
S.E. of regression & 4.689684 & Akaike info criterion & 6.157024 \\
Sum squared resid & 1275.602 & Schwarz criterion & 6.812081 \\
Log likelihood & -224.2810 & Hannan-Quinn criter. & 6.419655 \\
F-statistic & 17.68514 & Durbin-Watson stat & 2.475204 \\
Prob(F-statistic) & 0.000000 & & \\
\hline
\end{tabular}

Sumber: Output E-Views 9.0, data diolah

Berdasarkan tabel 6 di atas dapat dilihat bahwa nilai koefisien determinasi (Adjusted $R^{2}$ ) sebesar 0,816017 atau $81,6017 \%$. Dengan demikian menunjukkan bahwa variabel independen yaitu Likuiditas dan Struktur Modal mampu menjelaskan 81,6017\% terhadap total varians Profitabilitas, sedangkan 18,3983\% dari varians Profitabilitas dijekaskan oleh variabel yang tidak diteliti.

Tabel 7. Uji Koefisien Determinasi (Adjusted $R^{2}$ ) Sub struktur II Variabel dependen PBV

\begin{tabular}{lrll}
\hline R-squared & 0.926887 & Mean dependent var & 5.331875 \\
Adjusted R-squared & 0.898667 & S.D. dependent var & 7.233617 \\
S.E. of regression & 2.302663 & Akaike info criterion & 4.742034 \\
Sum squared resid & 302.2285 & Schwarz criterion & 5.426867 \\
Log likelihood & -166.6814 & Hannan-Quinn criter. & 5.016603 \\
F-statistic & 32.84592 & Durbin-Watson stat & 2.438880 \\
Prob(F-statistic) & 0.000000 & & \\
\hline Sumber: Output E-Views & 9.0 . & &
\end{tabular}

Berdasarkan tabel 7 di atas dapat dilihat bahwa nilai koefisien determinasi (Adjusted $R^{2}$ ) sebesar 0,89667 atau $89,667 \%$. Dengan demikian menunjukkan bahwa variabel independen yaitu Likuiditas dan Struktur Modal dan Profitabiltas mampu menjelaskan $89,667 \%$ terhadap total varians Nilai Perusahaan, sedangkan $10,333 \%$ dari varians Nilai Perusahaan dijelaskan oleh variabel yang tidak diteliti.

\subsection{Interpretasi Analisis Jalur}

Koefisien jalur (p) sama dengan koefisien regresi yang sudah standarisasi atau yang disebut juga dengan bobot beta $(\beta)$. Bobot beta mempunyai makna sebagai jumlah perubahan dalam variabel dependen yang dihubungkan dengan perubahan (kenaikan dan penurunan) dalam satu standar deviasi pada variabel bebas saat dilakukan pengendalian pengaruh terhadap variabel lainnya. (Sarwono, 2012: 35). Dalam penelitian ini, bobot beta dilihat dari nilai coefficient yang terdapat pada table 15 dan 16 di atas.

\section{Menghitung Pengaruh Langsung atau Direct Fffect (DE)}

Besarnya pengaruh langsung (Direct Effect) dari variabel independen CR dan DER serta ROA secara parsial dapat dilihat nilai dari nilai coefficient yang terdapat pada tabel 15 dan tabel 16 di atas. Untuk menghitung pengaruh langsung atau DE dilakukan sebagai berikut:

a. Pengaruh variabel $\mathrm{CR}$ terhadap ROA

$\beta \mathrm{X}_{3} \mathrm{X}_{1}=-0,018860$

b. Pengaruh variabel DER terhadap ROA

$\beta X_{3} X_{2}=-9,805094$

c. Pengaruh variabel $\mathrm{CR}$ terhadap PBV

$\beta \mathrm{yx}_{1}=-9,252982$

d. Pengaruh variabel DER terhadap PBV

$\beta \mathrm{yx}_{2}=10,33274$

e. Pengaruh variabel ROA terhadap PBV

$\beta \mathrm{yx}_{3}=0,270759$ 


\section{Menghitung Pengaruh Tidak Langsung atau Indirect Effect (IE)}

Untuk menghitung pengaruh tidak langsung maka dapat dilakukan dengan cara sebagai berikut:

a. Pengaruh variabel $\mathrm{CR}$ terhadap PBV melalui ROA

$\beta \mathrm{X}_{3} \mathrm{X}_{1} \times \mathrm{yyx}_{3}=(-0,018860 \times 0.270759)=-0,005106$

b. Pengaruh variabel DER terhadap PBV melalui ROA

$\beta \mathrm{X}_{3} \mathrm{X}_{2} \times \mathrm{yx}_{3}=(-9,805094 \times 0,270759)=-2,654817$

\subsection{Pembahasan}

\section{Pengaruh Likuiditas Terhadap Profitabilitas}

Berdasarkan hasil pengujian regresi data panel variabel Likuiditas (CR) berpengaruh signifikan terhadap Profitabilitas. Dengan tingkat signifikan sebesar 0,0192 di mana nilai ini lebih kecil dari tingkat signifikansi yaitu 0,05 , maka hipotesis pertama $\left(\mathrm{H}_{0} 1\right)$ ditolak dan $\left(\mathrm{H}_{\mathrm{a}} 1\right)$ diterima. Dengan demikian dapat disimpulkan bahwa hasil uji hipotesis pertama Likuiditas berpengaruh signifikan terhadap Profitabilitas. Artinya bahwa besar kecilnya tingkat likuiditas dalam suatu perusahaan akan berpengaruh terhadap profitabilitas. Pada koefisien regresi variabel likuiditas menunjukkan nilai sebesar 0,018860 artinya bahwa variabel likuiditas memiliki arah yang negatif terhadap profitabilitas. Arah negatif mengartikan bahwa CR memiliki pengaruh berlawanan dengan prediksi tingkat profitabilitas.

Dengan kata lain, hasil dari penelitian ini menunjukkan bahwa peningkatan ataupun penurunan tingkat likuiditas selama periode penelitian ini akan berpengaruh terhadap tingkat keuntungan perusahaan dengan pengaruh berlawanan yaitu apabila tingkat likuiditas rendah maka akan semakin kecil laba yang diperoleh perusahaan karena perusahaan harus melunasi utang jangka pendeknya, sebaliknya jika semakin tinggi tingkat likuiditas maka laba yang diperoleh juga akan semakin tinggi. Dengan tingkat likuiditas yang tinggi maka perusahaan mempunyai kemampuan untuk melunasi utang jangka pendeknya yang akan jatuh tempo sehingga keuntungan yang diperoleh perusahaan dapat digunakan untuk kegiatan operasional perusahaan yang lainnya.

Penelitian ini sesuai dengan penelitian terdahulu dari Sylvia Chen dan Hening (2015), dan Bunga Asri dan Sofie (2015), yang menyatakan bahwa Likuiditas berpengaruh signifikan terhadap profitabilitas.

\section{Pengaruh Struktur Modal Terhadap Profitabilitas}

Berdasarkan hasil pengujian regresi data panel yang sudah dilakukan di atas menunjukkan bahwa variabel Struktur Modal (DER) berpengaruh signifikan terhadap Profitabilitas (ROA). Dengan tingkat signifikansi sebesar 0,0003 di mana nilai ini lebih kecil dari tingkat signifikansi yaitu sebesar 0,05 . Maka hipotesis kedua $\left(\mathrm{H}_{0} 2\right)$ ditolak dan $\left(\mathrm{H}_{\mathrm{a}} 2\right)$ diterima. Sehingga dapat disimpulkan hasil uji hipotesis kedua menunjukkan bahwa Struktur Modal berpengaruh terhadap Profitabilitas. Artinya bahwa besar kecilnya penggunan utang oleh sebuah perusahaan akan sangat berpengaruh terhadap tingkat keuntungan yang diperoleh perusahaan.

Koefisien regresi variabel struktur modal memiliki nilai sebesar -9,805094 artinya bahwa variabel struktur modal mempunyai arah negatif terhadap profitabilitas, dan mempunyai pengaruh yang berlawanan dengan prediksi tingkat keuntungan perusahaan. Dengan kata lain apabila sturktur modal meningkat atau jumlah utang suatu perusahaan meningkat maka keuntungan atau laba yang diperoleh semakin rendah dan sebaliknya apabila jumlah utang yang digunakan peruahaan semakin kecil maka akan meningkatkan keuntungan bagi perusahaan.

Hal ini sesuai dengan pecking order theory dalam Sudana (2015, hlm 175) yang menyatakan bahwa dalam pengambalian keputusan pendanaan perusahaan akan menggunakan pendanaan internal yang berasal dari laba ditahan terlebih dahulu, apabila dana perusahaan belum mencukupi baru menggunakan dana eksternal yang berasal dari utang atau ekuitas. Dengan tingkat profitabilitas yang tinggi, maka perusahaan 
memperoleh keuntungan yang tinggi sehingga laba ditahannya pun juga akan meningkat dan akan menambah ketersediaan dalam membiayai aktivitas operasionalnya serta dapat lebih mengoptimalkan pendanaan yang bersumber dari dalam perusahaan. Hal tersebut akan menurunkan keinginan perusahaan untuk memilih opsi baik itu utang kepada pihak ketiga ataupun menerbitkan surat utang karena perusahaan tidak terlalu membutuhkan dana yang bersumber dari utang. Dengan pendanaan internal bagi berarti perusahaan telah menghindari atau menurunkan risiko kebangkrutan.

Penelitian ini sejalan dengan penelitian terdahulu yang dilakukan oleh Tania Iskandar, dkk (2014), I Gede dan Ni Gusti (2016), Hamidy R, dkk (2015) yang menyatakan bahwa Struktur Modal berpengaruh signifikan terhadap Profitabilitas.

\section{Pengaruh Likuiditas Terhadap Nilai Perusahaan}

Berdasarkan hasil pengujian regresi data panel diperoleh bahwa variabel Likuiditas tidak berpengaruh signifikan terhadap Nilai Perusahaan dengan tingkat signifikansi sebesar 0,9982 lebih besar dari $0,05(0,9982>0,05)$, maka hipotesis ketiga $\left(\mathrm{H}_{0} 3\right)$ diterima dan $\left(\mathrm{H}_{\mathrm{a}} 3\right)$ ditolak. Dapat disimpulkan bahwa likuiditas tidak berpengaruh signifikan terhadap nilai perusahaan. Hal ini menunjukkan bahwa besar kecilnya likuiditas tidak terlalu berpengaruh terhadap nilai perusahaan. Koefisisen regresi variabel likuiditas sebesar 9,252982 yang mengartikan bahwa variabel likuiditas memiliki arah negatif terhadap nilai perusahaan. Arah negatif ini menunjukkna bahwa likuiditas memiliki pengaruh yang berlawanan dengan prediksi nilai perusahaan. Tingkat likuiditas yang tinggi belum tentu dapat meningkatkan nilai perusahaan.

Dalam menilai suatu perusahaan para investor tidak melihat dari tingkat likuiditasnya dalam hal ini perusahaan mampu memenuhi kewajiban jangka pendeknya, tetapi cenderung melihat laba atau keuntungan yang diperoleh perusahaan. Karena apabila keuntungan yang dihasilkan perusahaan tinggi maka investor akan tertarik untuk berinvestasi di perusahaan tersebut.

Penelitian ini sesuai dengan penelitian terdahulu yang dilakukan oleh Yudha dan Ni Luh (2013) yang menyatakan bahwa likuiditas tidak berpengaruh signifikan terhadap nilai perusahaan.

\section{Pengaruh Struktur Modal Terhadap Nilai Perusahaan}

Berdasarkan hasil pengujian regresi data panel diperoleh bahwa variabel Struktur Modal berpengaruh signifikan terhadap Nilai perusahaan. Dengan nilai signifikansi sebesar 0,0000 di mana nilai tersebut lebih kecil dari nilai signifikan $0,05(0,0000<0,05)$, maka hipotesis keempat $\left(\mathrm{H}_{0} 4\right)$ ditolak dan $\left(\mathrm{H}_{\mathrm{a}} 4\right)$ diterima. Dapat disimpulkan hipotesis keempat bahwa Sturktur Modal berpengaruh signifikan terhadap Nilai Perusahaan. Hal ini berarti bahwa besar kecilnya jumlah utang yang digunakan perusahaan untuk kegiatan operasional perusahaan akan berpengaruh terhadap nilai perusahaan. Nilai koefisien variabel struktur modal sebesar 10,33274 menunjukkan bahwa struktur modal memiliki pengaruh positif terhadap nilai perusahaan. Arah posistf ini mengartikan bahwa sturktur modal memiliki pengaruh yang searah dengan prediksi nilai perusahaan.

Dengan kata lain, hasil penelitian ini menunjukkan bahwa peningkatan atau penurunan struktur modal selama periode penelitian berpengaruh terhadap nilai perusahaan. Apabila penambahan utang yang dilakukan perusahaan untuk melakukan ekspansi usaha maka akan meningkatkan nilai perusahaan. Sebaliknya apabila pengunaan utang yang kurang efektif maka akan menurunkan nilai perusahaan.

Penelitian terdahulu yang sesuai dengan penelitian ini adalah penelitian yang dilakukan oleh I Gede dan Ni Gusti (2016), Hamidy, R, dkk (2015) dan Barakat Abdallah (2014) yang menyatakan bahwa Struktur Modal berpengaruh signifikan terhadap Nilai Perusahaan. 


\section{Pengaruh Profitabilitas Terhadap Nilai Perusahaan}

Sesuai dengan hasil pengujian regresi data panel pada variabel Profitabilitas menunjukkan bahwa Protiabilitas berpengaruh signifikan terhadap Nilai Perusahaan. Dengan tingkat signifikansi sebesar 0,0001 di mana nilai tersebut lebih kecil dari nilai signifikansi yaitu $0,05(0,0001<0,05)$ maka hipotesis kelima $\left(\mathrm{H}_{0} 5\right)$ ditolak dan $\left(\mathrm{H}_{\mathrm{a}} 5\right)$ diterima. Sehingga dapat disimpulkan bahwa Profitabilitas berpengaruh signifikan terhadap Nilai Perusahaan. Hal ini menunjukkan bahwa besar kecilnya profitabilitas sangat berpengaruh terhadap nilai perusahaan.

Nilai koefisien regresi variabel profitabilitas sebesar 0,270759 yang berarti variabel profitabilitas mempunyai arah positif terhadap nilai perusahaan. Arah positif menunjukkan profitabilitas memiliki pengaruh yang searah dengan prediksi nilai perusahaan. Dengan demikian hasil penelitian ini menunjukkan bahwa peningkatan ataupun penurunan profitabilitas akan mempengaruhi nilai perusahaan. Dengan meningkatnya laba atau keuntungan maka harga saham di pasar juga akan meningkat yang akhirnya akan meningkatkan nilai perusahaan. Singnaling Theory menyatakan bahwa profitabilitas yang tinggi menunjukkan prospek perusahaan yang bagus sehingga investor akan merespon positif dan akan meningkatkan nilai perusahaan (Al-Fisah, 2016). Penelitian terdahulu yang sejalan dengan penelitian ini adalah penelitian ynag dilakukan oleh Barakat Abdallah (2014), Hamidy, R, dkk (2015), Al-Fisah, M dan Khuzaini (2016) serta I Gede dan Ni Gusti (2016) yang menyatakan bahwa profitabilitas berpengaruh signifikan terhadap nilai perusahaan.

\section{Pengaruh Likuiditas Terhadap Nilai Perusahaan melalui Profitabilitas}

Berdasarkan hasil pengujian regresi data panel melalui interprestasi jalur yang bertujuan untuk menguji pengaruh variabel likuiditas terhadap nilai perusahaan melalui profitabilitas. Hasil perhitungan tidak langsung menunjukkan bahwa Likuiditas tidak berpengaruh signifikan terhadap Nilai Perusahaan melalui Profitabilitas. Dengan nilai tidak langsung sebesar $-0,005106$ di mana nilai ini lebih kecil dari nilai pengaruh langsung CR terhadap PBV yaitu $-9,252982(-0,005106<-9,252982)$ maka hipotesis keenam $\left(\mathrm{H}_{0} 6\right)$ diterima dan $\left(\mathrm{H}_{\mathrm{a}} 6\right)$ ditolak.

Sehingga dapat disimpulkan hasil uji hipotesis keenam adalah Likuiditas tidak berpengaruh signifikan terhadap Nilai Perusahaan melalui Profitabilitas. Penelitian ini belum mampu untuk memperkuat pengaruh likuiditas terhadap nilai perusahaan melalui profitabilitas. Yang diperhatikan investor sebelum melakukan investasi di sebuah perusahaan adalah lebih cenderung pada peningkatan profitabilitas. Meningkatnya profitabilitas suatu perusahaan akan menarik minat para investor untuk melakukan investasi di perusahaan.

Penelitian ini sesuai dengan penelitian terdahulu yang dilakukan oleh Yudha dan Ni Luh (2013) yang menyatakan bahwa Likuiditas tidak berpengaruh signifikan terhadap Nilai Perusahaan melalui Profitabilitas.

\section{Pengaruh Struktur Modal Terhadap Nilai Perusahaan melalui Profitabilitas}

Berdasarkan hasil pengujian regresi data panel melalui interprestasi jalur yang bertujuan untuk menguji pengaruh variabel struktur modal terhadap nilai perusahaan melalui profitabilitas. Hasil perhitungan tidak langsung menunjukkan bahwa Struktur Modal tidak berpengaruh signifikan terhadap Nilai Perusahaan melalui Profitabilitas. Dengan nilai tidak langsung sebesar -2,654817 lebih kecil dari nilai penagruh langsung DER terhadap PBV yaitu sebesar 10,33274 $(-2,654817<10,33274)$, maka dapat disimpulkan hipotesis ketujuh $\left(\mathrm{H}_{0} 7\right)$ diterima dan $\left(\mathrm{H}_{\mathrm{a}} 7\right)$ ditolak. Sehingga hipotesis ketujuh adalah Struktur Modal tidak berpengaruh signifikan terhadap Nilai Perusahaan melalui Profitabilitas.

Penelitian ini belum mampu untuk memperkuat hubungan struktur modal terhadap nilai perusahaan melalui profitabilitas. Hal ini karena apabila pengunaan utang yang tinggi akan berdampak pada penurunan profitabilitas yang menyebabkan harga saham juga akan 
menurun yang kemudian akan menurunkan nilai perusahaan. Perusahaan yang memiliki tingkat utang yang tinggi akan berdampak pada risiko kebangkrutan dan para investor pun tidak tertarik untuk berinvestasi.

Penelitian bertentangan dengan penelitian terdahulu yang dilakukan oleh Al-Fisah, $\mathrm{M}$ dan Khuziani (2016) dan Hamidy, R, dkk (2015) yang menyatakan bahwa struktur modal berpengaruh signifikan terhadap nilai perusahaan melalui profitabilitas.

\section{SIMPULAN, KETERBATASAN Dan KONTRIBUSI PRAKTIS}

\subsection{Simpulan}

Berdasarkan hasil analisis data dan pembahasan pada bab sebelumnya, maka dapat disimpulkan sebagai berikut:

a. Variabel Likuiditas berpengaruh signifikan terhadap profitabilitas. Hal ini menunjukkan bahwa besar kecilnya tingkat likuiditas akan berpengaruh terhadap profitabilitas.

b. Variabel Struktur Modal berpengaruh signifikan terhadap Profitabilitas. Hal ini berarti tinggi rendahnya penggunanaan utang dalam suatu perusahaan akan berpengaruh terhadap profitabilitas.

c. Variabel likuiditas tidak berpengaruh signifikan terhadap nilai perusahaan. Ini menunjukkan bahwa besar kecilnya tingkat likuiditas belum tentu berpengaruh terhadap nilai perusahaan.

d. Variabel Struktur Modal berpengaruh signifikan terhadap Nilai Perusahaan. Apabila peningkatan utang yang dilakukan perusahaan dengan tujuan untuk ekspansi maka hal tersebut akan meningkatkan nilai perusahaan.

e. Variabel profitabilitas berpengaruh signifikan terhadap nilai perusahaan. Tinggi rendahnya tingkat keuntungan atau profitabilitas yang diperoleh perusahaan maka akan berpengaruh terhadap peningkatan nilai perusahaan.

f. Variabel likuiditas tidak berpengaruh signifikan terhadap nilai perusahaan melalui profitabilitas. Artinya bahwa penelitian ini belum mampu memperkuat hubungan antara likuditas dengan nilai perusahaan melalui profitabilitas.

g. Variabel struktur modal tidak berpengaruh signifikan terhadap nilai perusahaan melalui profitabilitas. Artinya bahwa penelitian ini belum mampu memperkuat hubungan antara struktur modal dengan nilai perusahaan melalui profitabilitas.

\subsection{Keterbatasan}

Dalam penelitian ini memiliki beberapa keterbatasan yang mungkin dapat menimbulkan pengaruh dalam hasil penelitian ini, diantaranya:

a. Data yang diperoleh dari sumber yang digunakan terdapat banyak perusahaan yang tidak memenuhi kriteria sampel dari penelitian ini sehingga dapat memperkecil jumlah sampel yang digunakan yaitu dari 37 perusahaan manufaktur sektor barang konsumsi selama periode 2013-2016 yang terdaftar di BEI menjadi 20 sampel perusahaan.

b. Penelitian ini hanya berfokus pada perusahaan sector barang konsumsi saja, sehingga belum mencakup keseluruhan perusahaan manufaktur yang terdaftar di BEI

c. Penelitian ini hanya menggunakan variabel Likuiditas, Struktur Modal dan Profitabilitas sebagai variabel independen untuk menjelaskan pengaruhnya terhadap nilai perusahaan. Sehingga penelitian ini mengabaikan faktor lain yang mungkin dapat mempengaruhi nilai perusahaan sebagai variabel dependen.

\section{DAFTAR PUSTAKA}

Ajija, S. R., Sari, D. W., Setianto, R. H., \& Primanti, M.R. (2011). Cara Cerdas Menguasai Eviews, Jakarta: Salemba Empat.

Al-Fisah, M.C., \& Khuzaini. (2016). Profitabilitas Memediasi Pengaruh Struktur Modal Terhadap Nilai Perusahaan, Jurnal Ilmu dan Riset Manajemen, Vol. 5, No. 5, Mei 2016. 
Anzlina, C., \& Rustam. (2013). Pengaruh Tingkat Likuiditas, Solvabilitas, Aktivitas dan Profitabilitas Terhadap Nilai Perusahaan, Jurnal Ekonomi, Vol 16, No 2, April 2013.

Brigham, E.F., \& Weston. (1994). Dasar-dasar Manajemen Keuangan, Jakarta: Erlangga.

Barakat, A. (2014). The Impact of Finansial Structure, Financial Leverage and Profitability on Companies Value, Research Journal of Finance and Accounting, Vol.5, No.1, 2014.

Bursa Efek Indonesia. (2017). Laporan Keuangan Tahunan Diakses 25 februari 2017,dari http:/www.idx.co.id/id

Chen, S., \& Hening Widi Oetomo. (2015). Pengaruh Leverage, Likuiditas dan Perputaran Modal Terhadap Profitabilitas, Jurnal Ilmu dan Riset Manajemen Volume 4, Nomor 10, Oktober 2015.

Fahmi, I. (2014). Manajemen Keuangan dan Pasar Modal, Jakarta: Mitra Kencana Media.

Ghozali, I. (2011). Aplikasi Analisis Multivariate dengan Program IBM SPSS 19, Edisi 5, Semarang: Badan Penerbit Universitas Diponegoro.

Harjito, A. \& Martono. (2014). Manajemen Keuangan, Edisi 2, Yogyakarta: Ekonisia.

Hamidy, R.R., (2015). Pengaruh Struktur Modal Terhadap Nilai Perusahaan Pada Perusahaan Properti dan Real Estate di Bursa Efek Indonesia, E-Jurnal Ekonomi dan Bisnis unud, Vol. 4, No. 10, 2015, hlm 665-682.

Iskandar, T. (2015). Pengaruh Perputaran Modal Kerja, Struktur Modal dan Likuidtas Terhadap Profitabilitas Perusahaan Industri \& Chemical di Bursa Efek Indonesia, JOM FEKON Vol. 1, $\quad$ Nomor 2, Oktober 2014.

Kasmir. (2014). Analisis Laporan Keuangan, Jakarta: Rajawali

Margaretha, F., (2011). Manajemen Keuangan Untuk Manajer Nonkeuangan, Jakarta: Erlangga.

Novita, Bunga Asri dan Sofie. (2015). Pengaruh Struktur Modal dan Likuiditas Terhadap Profitabilitas, e-Journal Akuntansi Trisakti. Volume. 2, Nomor. 1,Februari 2015, Hlm. 13 - 28.

Pratama, I.G.G.W., \& Ni Gusti, P.W. (2016). Pengaruh Struktur Modal dan Profitabilitas Terhadap Nilai Perusahaan dengan Kepemilikan Manajerial sebagai Pemoderasi, E-Jurnal Akuntansi Unud, Vol. 15. No 3, 2016, hlm 1796-1825.

Sariyana, B,. (2016). Pengaruh Perputaran Modal Kerja dan Likuiditas Terhadap Profitabilitas (studi: pada perusahaan food and beverages), e Journal Bisma Universitas Pendidikan Ganesha jurusan Manajemen. Volume 4, Tahun 2016.

Sitanggang, JP. (2013). Manajemen Keuangan Perusahaan Dilengkapi dengan Soal dan Penyelesaiannya, Jakarta: Mitra Wacana Media. 
Sjahrial, D., \& Purba, D. (2013). Analisis Laporan Keuangan Cara Mudah dan Praktis Memahami Laporan Keuangan, Edisi 2. Jakarta: Mitra Wacana Media.

Sudana, I. M. (2015). Teori dan Praktik Manajemen Keuangan Perusahaan, Edisi 2, Jakarta: Erlangga.

Sugiyono. (2014). Metode Penelitian Manajemen, Bandung: Alfabeta.

Supranto, J., \& Limakrisna, N. (2013). Petunjuk Praktis penelitian Ilmiah untuk Menyusun Skripsi, Tesis, dan Disertasi, Jakarta: Mitra Wacana Media.

Velnampy, T., \& Vickneswaran Anojan. 2014. Capital Structure, Liquidity Position and Their Impact on Profitability: A Study of Listed Telecommunication Firms in Colombo Stock Exchange (CSE), Sri Lanka, Research Journal of Finance and Accounting. Vol.5, No.9, 2014. 